\title{
DAMPAK PANDEMI COVID-19 TERHADAP USAHA MIKRO, KECIL, DAN MENENGAH (UMKM) DAN STRATEGI PENINGKATAN PEREKONOMIAN PEMILIK UMKM (STUDI KASUS DI DESA SURUHAN KABUPATEN SUKOHARJO)
}

\author{
Asiah Wati'1), Arrum Puspita Sari²) \\ 1)Fakultas Syariah, Universitas Islam Negeri Raden Mas Said Surakarta, Surakarta, Jawa Tengah, Indonesia \\ ${ }^{2)}$ Akuntansi Syariah, Fakultas Ekonomi dan Bisnis Islam, Universitas Islam Negeri Raden Mas Said Surakarta, \\ Surakarta, Jawa Tengah, Indonesia \\ Corresponding author: Arrum Puspita Sari \\ E-mail : arrumpuspita20@gmail.com
}

Diterima 28 November 2021, Direvisi 11 Desember 2021, Disetujui 11 Desember 2021

\begin{abstract}
ABSTRAK
Pengabdian ini merupakan bentuk hasil kegiatan pengabdian kepada masyarakat yang memiliki tujuan untuk mengetahui dampak pandemi Covid-19 terhadap perekonomian masyarakat di desa Suruhan khususnya pada pelaku UMKM, serta untuk mengetahui strategi yang tepat bagi pelaku UMKM dalam meningkatkan perekonomian. Jenis pengabdian ini adalah penelitian kualitatif. Teknik pengumpulan data melalui wawancara dengan menggunakan data primer. Responden dalam pengabdian ini adalah 11 pemilik UMKM di desa Suruhan, kabupaten Sukoharjo. Hasil dari pengabdian ini menunjukkan bahwa pandemi Covid-19 berdampak negatif terhadap perekonomian masyarakat di desa Suruhan seperti kesusahan dalam mencari pekerjaan, maraknya PHK terhadap karyawan, kesusahan dalam berjualan, dan kesulitan dalam memenuhi kebutuhan hidup. Adapun strategi peningkatan perekonomian yang sangat efektif dalam meningkatkan penjualan produk UMKM di masa pandemi Covid-19 yaitu dengan melakukan jual beli secara Online.
\end{abstract}

Kata kunci: ekonomi; dampak covid-19; umkm; bisnis online.

\begin{abstract}
This service is a form of community service activity which has the aim of knowing the impact of the Covid-19 pandemic on the economy of the community in Suruhan village, especially for MSME actors, and to find out the right strategy for MSME actors in improving the economy. This type of service is qualitative research. Data collection techniques through interviews using primary data. Respondents in this service are 11 MSME owners in Suruhan village, Sukoharjo district. The results of this service show that the Covid-19 pandemic has a negative impact on the economy of the community in Suruhan village such as difficulty in finding work, rampant layoffs for employees, difficulties in selling, and difficulties in meeting the necessities of life. The strategy for increasing the economy is very effective in increasing sales of MSME products during the Covid-19 pandemic, namely by buying and selling online.
\end{abstract}

Keywords: economy; the impact of covid-19; smes; online business.

\section{PENDAHULUAN}

Pada saat ini, beberapa Negara di dunia sedang sibuk melawan virus yang disebut dengan Covid-19 (Corona Virus Disease 2019). Sejak diumumkan oleh World Healty Organisation (WHO) pada tanggal 11 Maret 2020, Covid-19 menjadi wabah global yang penyebarannya sangatlah cepat (Yamali \& Putri, 2020). Di Indonesia, beberapa kebijakan telah diambil untuk mengatasi permasalahan ini. Mulai dari penggunaan masker ketika beraktivitas, menerapkan social distancing, work from home, Pembatasan Sosial Berskala Besar (PSBB), hingga lockdown (Muliati, 2020).
Virus Corona merupakan zoonotic yang memiliki makna penularan antara manusia dan binatang (Hanoatubun, 2020). Atas dasar informasi dari Kementrian Kesehatan Indonesia, perkembangan awal kasus Covid-19 di Wuhan terjadi pada tanggal 30 Desember 2019, dimana keluar pernyataan dari Wuhan Municipal Health Committee, "Urgent notice on the treatment of pneumonia of unknown cause" (Zulkipli \& Muharir, 2021). Penyebaran virus Corona yang semakin meningkat di berbagai belahan dunia telah memberikan dampak terhadap perekonomian.

Semakin bertambahnya kasus positif setiap harinya, membuat dikeluarkannya 
Peraturan Pemerintah Nomor 21 Tahun 2020 tentang Pembatasan Sosial Berskala Besar (PSBB), dengan tujuan untuk memutus mata rantai penyebaran virus Corona (Aliyani Firdaus et al., 2020). Adanya keputusan pemilik usaha untuk merumahkan atau melakukan PHK kepada karyawan menyebabkan angka pengangguran meningkat secara signifikan (Zubaidah et al., 2021). Pemutusan hubungan kerja juga mengakibatkan masyarakat miskin meningkat (Yenti Sumarni, 2020). Tingkat pengangguran menurut data dari Badan Pusat Statistik (BPS) pada Februari 2021 mencapai 8,75 juta orang atau $6,26 \%$ dari jumlah angkatan kerja (bps.go.id).

Indonesia merupakan salah satu negara yang terdampak akibat pandemi Covid19 terutama di sektor perekonomian. Pandemi Covid-19 mengakibatkan sulitnya mencari pekerjaan, sulitnya memenuhi kebutuhan hidup dikarenakan tidak adanya penghasilan, banyaknya tempat usaha yang memberhentikan karyawannya akibat penurunan tingkat penjualan, dan masalahmasalah lain yang banyak dialami masyarakat di sektor perekonomian. Sampai dengan 17 April 2020, sebanyak 37.000 pelaku UMKM melaporkan diri kepada Kementerian Koperasi dan UKM terdampak pandemi Covid-19 (Sugiri, 2020).

Menurut rilis data dari Kementerian Koperasi dan UKM, kesulitan yang dialami oleh UMKM selama pandemi itu terbagi dalam empat masalah. Pertama, terdapat penurunan penjualan karena berkurangnya aktifitas masyarakat di luar sebagai konsumen. Kedua, kesulitan permodalan karena perputaran modal yang sulit sehubungan tingkat penjulan yang menurun. Ketiga, adanya hambatan distribusi produk karena adanya pembatasan pergerakan penyaluran produk di wilayah-wilayah tertentu. Keempat, adanya kesulitan bahan baku karena sebagai UMKM menggantungkan ketersediaan bahan baku dari sektor industri lain (Sugiri, 2020).

Perkembangan UMKM yang sangat pesat tidak lepas dari dukungan dan pemanfaatan sarana teknologi, informasi, dan komunikasi. Munculnya pandemi Covid-19 memberikan dampak terhadap perekonomian khususnya UMKM. Akibatnya, pertumbuhan UMKM pun juga mengalami penurunan (Aliyani Firdaus et al., 2020). Banyak usaha kecil yang terpaksa menutup usahanya untuk sementara waktu (Sugiri, 2020). Menurut Kementerian Keuangan, pandemi Covid-19 ini memberikan dampak negatif terhadap perekonomian domestik, seperti turunnya daya beli masyarakat, eksistensi UMKM, ancaman terhadap sektor perbankan dan keuangan, serta penurunan kinerja perusahaan (Suryani, 2021).

Kabupaten Sukoharjo merupakan kabupaten yang berada di provinsi Jawa Tengah dengan mayoritas penduduknya bekerja sebagai petani, peternak, pedagang, pengusaha, karyawan, dan buruh. Adanya pandemi Covid-19 memberikan dampak terhadap perekonomian masyarakat khususnya di desa Suruhan. Banyak masyarakat yang mengeluh akibat adanya pembatasan aktivitas karena adanya Pemberlakuan Pembatasan Kegiatan Masyarakat (PPKM). Berdasarkan data observasi menunjukkan bahwa perlu dilakukan penelitian yang bertujuan untuk mengetahui dampak dari pandemi Covid-19 bagi pemilik UMKM di desa Suruhan, Kabupaten Sukoharjo, Jawa Tengah.

Meskipun perekonomian sedang melemah, namun disisi lain perekonomian juga mengalami peningkatan. Di Indonesia sendiri sudah banyak perusahaan atau pemilik usaha yang bergerak di bidang e-commercee atau bisnis Online yang berhasil mengalami peningkatan pendapatan. Hal ini disebabkan karena konsumen lebih aktif berbelanja secara Online dibandingkan secara Offline karena adanya social distancing untuk mencegah penularan virus Corona (Ayu \& Lahmi, 2020). Dengan demikian, para pelaku UMKM memiliki peluang emas dalam memajukan usahanya melalui perdagangan elektronik. Pandemi Covid-19 ini menjadi momentum bagi pelaku UMKM untuk berkembang, salah satunya dengan beralih ke bisnis Online (Lili Marlinah, 2020).

Strategi bertahan yang bisa dilakukan oleh UMKM adalah dengan melakukan perdagangan secara Online atau e-commercee, melakukan promosi secara digital, serta menjalin hubungan pemasaran dengan pelanggan yang optimal (W. laura Hardilawati, 2020). Penelitian yang dilakukan oleh Helmalia \& Afrinawati (2018) menunjukkan bahwa bisnis Online atau e-commercee berpengaruh positif dan signifikan dalam upaya peningkatan kinerja serta pendapatan UMKM. Namun, hasil yang berbeda dengan penelitian yang dilakukan oleh W. L. Hardilawati et al. (2019) yang menunjukkan bahwa e-commercee memiliki pengaruh positif namun tidak signifikan dalam meningkatkan kinerja pemasaran untuk usaha kecil.

Berdasarkan latar belakang permasalahan ini, maka dapat dirumuskan bahwa permasalahan dalam penelitian ini adalah 1) Apakah dampak dari pandemi Covid19 bagi pemilik UMKM di desa Suruhan? dan 2) Bagaimana strategi yang dapat dilakukan oleh pemilik UMKM di desa Suruhan untuk 
meningkatkan pendapatan di masa pandemi Covid-19?. Tujuan dari penelitian ini adalah untuk mengetahui apa dampak dari pandemi Covid-19 bagi pemilik UMKM di desa Suruhan dan untuk mengetahui bagaimana strategi yang dapat dilakukan oleh pemilik UMKM di desa Suruhan dalam rangka meningkatkan pendapatan di masa pandemi Covid-19.

Penelitian ini diharapkan mampu memberikan manfaat serta bisa menambah wawasan ilmu pengetahuan, dan menjadi sumber referensi tambahan yang dapat dijadikan bahan acuan untuk penelitian selanjutnya. Penelitian ini memiliki fokus pembahasan mengenai dampak pandemi Covid-19 terhadap UMKM di desa Suruhan serta strategi yang dilakukan untuk meningkatkan perekonomian selama pandemi Covid-19. Sehingga judul penelitian ini adalah "Dampak Pandemi Covid-19 Terhadap Usaha Mikro, Kecil, dan Menengah (UMKM) Dan Strategi Peningkatan Perekonomian Pemilik UMKM (Studi Kasus di Desa Suruhan Kabupaten Sukoharjo)".

\section{METODE}

Pengabdian ini dilakukan selama 30 hari tepatnya pada bulan Juni 2021. Metode pada penelitian ini adalah metode penelitian deskriptif kualitatif. Gejala-gejala yang timbul akibat Covid-19 dan dampaknya terhadap kelangsungan hidup UMKM di desa Suruhan akan dikumpulkan, dikaji, dan dideskripsikan serta strategi jitu nya untuk mengembangkan UMKM di masa pandemi Covid-19. Data yang digunakan dalam penelitian ini adalah data primer. Data primer merupakan data yang diperoleh langsung dari responden (Sugiyono, 2010). Teknik pengumpulan data dilakukan dengan wawancara. Wawancara merupakan teknik pengumpulan data dengan percakapan untuk memperoleh informasi secara langsung dari kedua belah pihak yaitu pewawancara dan pihak yang diwawancarai (Raco, 2010). Wawancara dilakukan dengan 11 pemilik UMKM di desa Suruhan, Kabupaten Sukoharjo. Adapun teknik penelitian yang digunakan dalam penelitian ini meliputi triangulasi sumber data dan member checks. Triangulasi sumber yang dilakukan dengan cara mengecek data yang telah diperoleh melalui beberapa sumber (Reza, 2016). Dalam hal ini dilakukan pengumpulan dan pengujian data yang telah diperoleh. Kemudian data yang sudah diperoleh dari narasumber dideskripsikan dan dikategorikan mana pandangan yang sama dan mana pandangan yang berbeda. Data yang telah dianalisis tersebut kemudian disimpulkan. Pada teknik member checks, dilakukan wawancara secara mendalam dengan narasumber yang direkam dengan video recorder selama pengumpulan data, kemudian data tersebut di transkripsikan.

Penelitian ini dilakukan melalui empat tahapan, yaitu:

1. Tahap Identifikasi Masalah dan Potensi Pada tahap pertama ini, peneliti mencari informasi mengenai profil desa, tata letak, perekonomian masyarakat, permasalahan ekonomi yang dihadapi oleh masyarakat, serta potensi yang ada di desa Suruhan. Kegiatan ini dilakukan dengan wawancara langsung bersama masyarakat.

2. Tahap Analisis dan Perencanaan Pada tahap kedua, dilakukan analisis terhadap permasalahan dan potensi yang sudah diketahui. Selanjutnya ditentukan rencana-rencana yang akan dilaksanakan di tahap berikutnya guna untuk mengatasi permasalahan yang ada berdasarkan potensi di desa Suruhan.

3. Tahap Aksi Partisipatif

Pada tahap ketiga, rencana-rencana yang sudah disusun pada tahap kedua mulai direalisasikan. Kegiatan ini melibatkan masyarakat setempat untuk ikut serta dalam kegiatan.

4. Tahap Monev Partisipatif

Pada tahap terakhir, dilakukan monitoring dan evaluasi kegiatankegiatan yang telah dilaksanakan pada tahap ketiga. Kegiatan ini dilakukan dengan melakukan wawancara langsung dengan masyarakat.

\section{HASIL DAN PEMBAHASAN}

Usaha Mikro, Kecil dan Menengah (UMKM) Usaha Mikro, Kecil dan Menengah (UMKM) menurut Undang-Undang Nomor 20

Pasal 1 Tahun 2008 (Suci, 2017) yaitu:

1. Usaha mikro adalah usaha produktif yang dimiliki oleh perorangan maupun badan usaha perorangan yang telah memenuhi kriteria sebagai usaha mikro seperti yang telah diatur di dalam Undang-Undang ini.

2. Usaha kecil adalah usaha ekonomi produktif yang berdiri sendiri, yang dimiliki oleh perorangan maupun badan usaha yang bukan merupakan anak perusahaan ataupun cabang perusahaan yang dimiliki dan dikuasai baik secara langsung maupun tidak langsung dari usaha menengah atau usaha besar yang telah memenuhi kriteria usaha kecil sebagaimana yang dimaksud di dalam Undang-Undang 
ini.

3. Usaha menengah adalah usaha ekonomi produktif yang berdiri sendiri, yang dilakukan oleh perorangan ataupun badan usaha yang bukan merupakan anak perusahaan atau cabang perusahaan yang dimiliki dan dikuasai baik secara langsung maupun tidak langsung dengan usaha kecil atau usaha besar dengan hasil penjualan tahunan atau jumlah kekayaan bersih sebagaimana yang diatur di dalam Undang-Undang ini.

4. Usaha besar adalah usaha ekonomi produktif yang dilakukan oleh badan usaha dengan hasil penjualan tahunan atau total kekayaan bersih lebih besar dari usaha menengah yang terdiri dari usaha nasional milik negara ataupun swasta, usaha patungan, dan usaha asing yang melakukan kegiatan perekonomian di Indonesia.

5. Dunia usaha adalah usaha mikro, usaha kecil, usaha menengah dan usaha besar yang melakukan kegiatan ekonomi di Indonesia dan menetap di Indonesia

\section{Kriteria Usaha Mikro, Kecil dan Menengah (UMKM)}

Menurut Pasal 6 UU Nomor 20 Tahun 2008 tentang kriteria UMKM dalam bentuk permodalan (Suci, 2017) adalah sebagai berikut:

1. Kriteria Usaha Mikro adalah sebagai berikut:

a. Memiliki kekayaan bersih paling banyak Rp50.000.000,00 (lima puluh juta rupiah) tidak termasuk tanah dan bangunan tempat usaha; atau

b. Memiliki hasil penjualan tahunan paling banyak Rp300.000.000,00 (tiga ratus juta rupiah).

2. Kriteria Usaha Kecil adalah sebagai berikut:

a. Memiliki kekayaan bersih lebih dari Rp50.000.000,00 (lima puluh juta rupiah) sampai dengan paling banyak Rp500.000.000,00 (lima ratus juta rupiah) tidak termasuk tanah dan bangunan tempat usaha; atau

b. Memiliki hasil penjualan tahunan lebih dari Rp300.000.000,00 (tiga ratus juta rupiah) sampai dengan paling banyak Rp2.500.000.000,00 (dua milyar lima ratus juta rupiah).

3. Kriteria Usaha Menengah adalah sebagai berikut:

a. Memiliki kekayaan bersih lebih dari Rp500.000.000,00 (lima ratus juta rupiah) sampai dengan paling banyak Rp10.000.000.000,00 (sepuluh milyar rupiah) tidak termasuk tanah dan bangunan tempat usaha; atau

b. Memiliki hasil penjualan tahunan lebih dari Rp2.500.000.000,00 (dua milyar lima ratus juta rupiah) sampai dengan paling banyak Rp50.000.000.000,00 (lima puluh milyar rupiah).

\section{Perekonomian Masyarakat Sebelum Adanya Pandemi Covid-19}

Berdasarkan data hasil wawancara bersama masyarakat, mayoritas mengatakan bahwa penjualan sebelum adanya pandemi Covid-19 terbilang baik dan menghasilkan omset yang maksimal. "Sebelum ada pandemi Covid-19, saya jualannya kan sampai malam dan justru di malam hari itu pembeli sedang ramai-ramainya yang membuat dagangan saya cepat habis. Terlebih lagi saya sudah punya langganan, jadi enak jualannya. Dan alhamdulillah keuntungan yang diperoleh juga optimal.", ujar narasumber $X$.

Narasumber $\mathrm{Y}$ mengatakan bahwa, "Sebelum adanya Corona, Alhamdulillah dagangan saya juga laku mbak, walaupun masih sering ada sisa dagangan yang belum laku terjual. Tetapi keuntungan yang saya peroleh masih stabil dan cukup untuk memenuhi kebutuhan hidup". Keuntungan yang stabil ini juga dialami oleh beberapa pedagang yang lain, seperti narasumber $R, S, T, U, V$,dan W. Hal ini dikarenakan jam operasional berjualan yang tidak ada batasan dan tidak ada anjuran untuk berjaga jarak.

Dari hasil wawancara tersebut, diketahui bahwa mayoritas masyarakat mengatakan bahwa sebelum adanya pandemi Covid-19 penghasilan yang mereka peroleh masih stabil dan tidak mengalami kerugian yang sangat signifikan. Karena mereka leluasa dalam menjajakan dagangannya tanpa adanya batas waktu, sehingga mereka akan berjualan sampai dagangannya habis. Terlebih lagi banyaknya pembeli yang sudah menjadi langganan membuat pedagang tidak terlalu sulit dalam memperdagangnya produk atau jasanya.

Namun, menurut narasumber $Z$ omzet penjualan yang diperoleh sebelum adanya pandemi Covid-19 justru lebih rendah dibandingkan pada saat pandemi Covid-19. "Sebelum ada Covid-19, jualannya ya lancarlancar saja, ada keuntungan juga yang diperoleh. Namun, keuntungan tersebut tidak sebesar keuntungan yang diperoleh pada saat pandemi Covid-19. Hal ini dikarena saya masih berjualan secara keliling dan belum mulai berjualan secara Online, serta produk yang saya perjualbelikan juga terbatas hanya pada satu produk saja. Namun, keuntungan masih 
tetap saya dapatkan dalam artian masih stabil.", ujar narasumber $\mathbf{Z}$.

Dapat disimpulkan bahwa sebelum adanya pandemi Covid-19, perekonomian masyarakat berjalan dengan lancar dan stabil. Tidak ada keluhan yang dirasakan oleh para pemilik usaha, karena semuanya berjalan dengan normal. Para pedagang pun bisa berjualan dengan leluasa tanpa batasan waktu, dan tentunya omzet penjualan pun juga stabil bahkan cenderung meningkat. Namun, ada beberapa pedagang yang justru merasakan bahwa keuntungan yang diperoleh pada saat pandemi Covid-19 jauh lebih banyak dibandingkan sebelum adanya pandemi Covid19. Hal ini dikarenakan sistem jualan yang mulai beralih ke sistem penjualan $\underline{\text { Online. }}$.

\section{Perekonomian Masyarakat Setelah Adanya Pandemi Covid-19}

Berdasarkan data resmi pemerintah per tanggal 04 Agustus 2021, jumlah kasus Covid-19 di Indonesia yang sudah terkonfirmasi adalah sebanyak 3.496 .700 kasus (covid19.go.id). Dengan adanya himbauan dari pemerintah untuk stay at home dan menjauhi kerumunan, hal ini memiliki pengaruh terhadap UMKM. Guna mendukung pemulihan ekonomi nasional di masa pandemi Covid-19, melalui Peraturan Menteri Koperasi, Usaha Kecil dan Menengah Republik Indonesia Nomor 6 Tahun 2020 tentang pedoman umum penyaluran bantuan pemerintah bagi pelaku UMKM, pemerintah telah berupaya untuk membantu keberlangsungan UMKM (Koperasi, 2020).

Dalam upaya membantu UMKM untuk tetap bertahan di masa pandemi Covid-19, pemerintah memberikan beberapa kebijakankebijakan yang diharapkan dapat membantu memulihkan UMKM (Sugiri, 2020). Melalui Peraturan Menteri Koperasi, Usaha Kecil dan Menengah Republik Indonesia Nomor 6 Tahun 2020 tentang pedoman umum penyaluran bantuan pemerintah bagi pelaku UMKM, pemerintah telah berupaya untuk membantu keberlangsungan UMKM (Koperasi, 2020). Keberhasilan kebijakan pemerintah tersebut sangat bergantung pada komponen pelaku usaha di masyarakat. Oleh karenanya, dibutuhkan dukungan dan kerjasama antara dua belah pihak untuk perekonomian yang lebih baik (Sugiri, 2020).

Berdasarkan hasil wawancara bersama para pemilik usaha, rata-rata UMKM mengalami penurunan pendapatan selama adanya pandemi Covid-19, khususnya pada saat diberlakukan PPKM. Narasumber $Y$ sebagai pedagang bakso mengatakan bahwa, "Adanya PPKM mengakibatkan penurunan pendapatan. Waktu berjualan yang sangat terbatas mengharuskan pulang meskipun dagangan masih banyak. $\mathrm{Hal}$ ini mengakibatkan kerugian, karena barang yang terjual tidak menutupi modal yang sudah dikeluarkan. Oleh karenanya untuk beberapa hari ini libur dahulu jualannya".

Menurut narasumber W sebagai pemilik usaha laundry mengatakan, "Sejak adanya pandemi Covid-19 ini pendapatan saya turun drastis bahkan sampai $50 \%$, banyak orang yang takut untuk keluar rumah. Mereka takut jika pakaiannya dicuci di tempat laundry akan terkena virus, padahal saya juga mengantisipasi hal tersebut dengan mencuci pakaian secara berulang kali dengan sabun yang cukup banyak agar pakaian benar-benar bersih. Namun, hal tersebut tidak terlalu berpengaruh dalam meningkatkan pendapatan saya". Penurunan pendapatan ini juga dirasakan oleh beberapa pemilik usaha lainnya seperti narasumber $\mathrm{R}, \mathrm{S}, \mathrm{T}, \mathrm{U}$, dan V.

Berdasarkan hasil wawancara dengan beberapa pedagang, banyak pedagang yang mengeluh akibat diterapkannya PPKM, hal tersebut mengakibatkan minimnya ruang bagi para pedagang untuk menjajakan dagangannya. Selain itu, adanya virus Corona membuat masyarakat menjadi cemas dan lebih waspada terhadap segala sesuatu, termasuk dalam memenuhi kebutuhan hidupnya. Banyak pedagang atau pemilik usaha yang mengalami penurunan omzet yang cukup siginifikan, akibat produk atau jasa yang mereka perjualbelikan tidak selaku sebelum adanya pandemi Covid19.

Namun, terdapat perbedaan dengan yang dialami oleh narasumber $Q$ dan narasumber Z. Pada masa pandemi Covid-19 ini justru omset penjualan yang mereka dapatkan meningkat berkali-kali lipat dibandingkan sebelum adanya pandemi Covid19. Hal ini dikarenakan mereka mulai merambah ke dunia bisnis Online. Dengan adanya bantuan biaya modal untuk UMKM dari pemerintah, beliau memanfaatkannya untuk mengembangkan usahanya. Bantuan tersebut beliau gunakan untuk menambah produkproduk yang akan ia perjualbelikan secara Online.

"Pada saat pandemi Covid-19 ini justru saya tidak merasakan dampaknya, karena saya mulai berjualan secara Online sehingga tidak ada pengaruhnya dengan pandemi Covid19. Justru semenjak berjualan Online ini pendapatan saya meningkat hingga empat kali lipat karena saya rutin melakukan promosi setiap harinya di story WhatsApp. Dengan bantuan BPUM akhirnya saya bisa menambah produk jualan menjadi bakso ayam, tahu bakso, somay, jeladren bakso ayam, jeladren somay, 
ayam potong, telur ayam, gas Ipj, dan isi ulang air minum", ujar narasumber Z. Hal yang sama juga dialami oleh beberapa pedagang lainnya yang sudah merambah ke dunia bisnis Online, seperti narasumber $P$ dan narasumber $Q$.

Dari hasil wawancara tersebut, dapat diketahui bahwa pandemi Covid-19 tidak selamanya memberikan dampak negatif bagi masyarakat. Masyarakat yang kritis akab berusaha mencari celah-celah bisnis yang bisa dijalankan di masa pandemi Covid-19. Pembatasan aktivitas masyarakat mengakibatkan sebagian besar kegiatan masyarakat hanya dilakukan di dalam rumah. Untuk memenuhi kebutuhan hidup, tidak sedikit masyarakat yang melakukan transaksi jual beli secara Online. Hal ini dilakukan sebagai upaya untuk menjaga diri dari penyebaran virus Corona, serta untuk mengefisienkan waktu dan juga tenaga. Oleh karenanya, berjualan secara Online menjadi strategi yang sangat efektif bagi pemilik usaha dalam rangka meningkatkan angka penjualan. Berdasarkan wawancara di atas, penjualan Online sudah terbukti mampu meningkatkan pendapatan UMKM di masa pandemi Covid-19.

\section{Strategi Yang Dilakukan Masyarakat Untuk Meningkatkan Pendapatan Di Masa Pandemi Covid-19}

Ditengah pandemi Covid-19 ini, penjualan pada umumnya mengalami penurunan karena masyarakat yang lebih banyak beraktivitas di rumah. Selain itu, banyak UMKM yang memilih untuk menutup toko karena adanya PPKM yang mengakibatkan sepinya pelanggan. Salah satu solusi yang bisa dilakukan untuk tetap menjalankan usaha serta memperluas jangkauan konsumen adalah dengan mengembangkan usaha melalui $e-$ commercee atau bisnis Online. E-commercee merupakan suatu proses transaksi jual beli yang dilakukan oleh produsen dan konsumen secara elektronik melalui internet (W. laura Hardilawati, 2020).

Penjualan Online (e-commerce) merupakan sistem penjualan secara elektronik dengan menggunakan digital marketing (W. laura Hardilawati, 2020). E-commerce adalah suatu konsep yang menjelaskan mengenai proses transaksi jual beli dan pertukaran produk, service, dan informasi melalui jaringan komputer yaitu internet (Juanita, 2017). Ecommerce merupakan penyebaran, penjualan, pemasaran barang dan jasa, serta pembelian secara Online melalui sistem elektronik dengan cara transfer dana elektronik (Reza, 2016).

Ada beberapa tipe e-commerce (Juanita, 2017), yaitu:
1. Collaborative
Commerce

commerce)

2. B2C (Business to Customer)

3. $B 2 B$ (Business to Business)

4. C2C (Costumer to Costumer)

5. Intrabusiness (Intraorganizational) Commerce

6. Government To Citizens (G2C)

7. Mobile Commerce (M-Commerce)

Dari beberapa tipe tersebut, tipe yang paling sering diaplikasikan adalah tipe Business to Customers (B2C) yang meliputi electronic retailing dengan cara mendesain sendiri, electronic storefronts dengan data diambil langsung dari satu sumber, dan electronic mails dengan cara melakukan belanja melalui internet (Juanita, 2017).

Penjualan Online merupakan solusi alternatif dalam meningkatkan penjualan pada masa pandemi Covid-19. Dengan e-commerce, pelaku usaha harus melakukan pemasaran produk secara digital melalui sosial media. Digital marketing akan membantu pelaku usaha dalam mepromosikan dan memasarkan produk dan jasa yang mereka jualbelikan dan mampu memperluas pasar baru yang sebelumnya tertutup atau terbatas karena adanya keterbatasan waktu, jarak dan cara berkomunikasi (Prabowo, 2018).

Strategi pemasaran yang bisa dilakukan untuk meningkatkan penjualan (Permata Sari, 2020) terdiri dari:

1. Kemudahan

Pemasaran secara digital lebih mengedepankan kesederhanaan dalam berbelanja tanpa harus melakukan banyak pengorbanan seperti tenaga, waktu dan biaya lain di luar pembelian. Pembeli dapat melakukan transaksi dimana saja dan dalam kondisi apapun. Karena alasan tersebut, model pemasaran digital lebih cepat direspon dan dalam waktu singkat bisa menjadi gaya hidup masyarakat perkotaan (urban).

2. Efisiensi Harga

Para pelaku usaha harus bisa mewujudkan bagaimana waktu dan biaya dapat diminimalkan dengan cara apapun. Para konsumen menginginkan kemudahan namun dengan biaya dan waktu yang minim, pertimbangan ini menjadi alasan mengapa konsumen lebih menyukai pemasaran digital. Faktanya pemasaran digital lebih menawarkan keterjangkauan harga, lebih hemat dan irit.

3. Fleksibilitas metode pembayaran Pembelian produk atau jasa secara digital yang dilengkapi dengan fitur 
pembayaran yang mudah dan lengkap akan membuat konsumen semakin tertarik dengan pembelian Online. Hal ini dikarenakan konsumen ingin mendapatak kemudahan dalam berbelanja. Dengan adanya metode pembayaran digital, akan mempersingkat waktu dan tenaga dalam melakukan transaksi jual beli.

4. Pelayanan yang baik

Pelayanan adalah faktor non strategis langsung dalam penjualan, tetapi pelayanan merupakan faktor eksternal yang telah terbukti dapat mempengaruhi emosional konsumen untuk melakukan pembelian. Oleh karena itu, sangat penting bagi perusahaan untuk membangun model pelayanan yang baik dengan konsumen, perusahaan harus melakukan berbagai cara agar seluruh potensi yang dimiliki dapat menjadi sarana pelayanan terhadap konsumen.

Di era revolusi industri 4.0, memang sudah seharusnya pelaku usaha mulai merintis usahanya secara Online. Sekarang pola belanja masyarakat mulai bergeser ke sistem

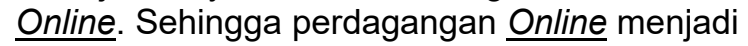
pilihan yang baik bagi pelaku usaha untuk mengembangkan usaha dan meningkatkan pendapatan. Lebih jauh lagi, berjualan secara

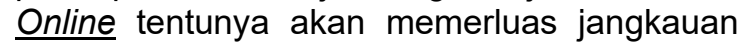
pasar. Jika berjualan secara Offline, konsumen hanya terdiri dari masyarakat sekitar, namun dengan bisnis Online konsumen bisa berasal dari daerah manapun, yang mana membuat produk UMKM akan terkenal dan tersebar luas. Selain itu, yang tidak kalah penting dari suatu bisnis Online adalah kegiatan promosi. Oleh karenanya untuk menarik minat konsumen, pemilik usaha harus rutin melakukan promosi dengan cara yang unik dan menarik.

Penelitian ini sejalan dengan penelitian yang dilakukan oleh Helmalia \& Afrinawati (2018) dimana dalam penelitiannya menyatakan bahwa bisnis Online atau ecommerce berpengaruh positif dan signifikan dalam meningkatan kinerja dan pendapatan UMKM. Dengan bisnis Online, pendapatan masyarakat akan mengalami peningkatan yang signifikan dan mampu bertahan di masa pandemi Covid-19. Karena bisnis Online bisa dilakukan dimana saja dan tidak terbatas oleh tempat dan waktu berjualan.

\section{SIMPULAN DAN SARAN Simpulan}

$\begin{array}{ccr}\text { Pandemi } & \text { Covid-19 memberikan } \\ \text { pengaruh yang } & \text { signifikan } & \text { terhadap }\end{array}$ perekonomian masyarakat khususnya UMKM.
Mayoritas UMKM mengalami penurunan pendapatan, dengan diterapkannya Pemberlakuan Pembatasan Kegiatan Masyarakat (PPKM) membuat pemilik usaha memilih untuk berhenti beroperasi dalam beberapa waktu. Oleh karenanya, banyak karyawan yang mengalami pemberhentian kerja $(\mathrm{PHK})$ sehingga menimbulkan masalah pengangguran di masyarakat. Mayoritas pedagang mengalami penurunan tingkat penjualan yang sangat drastis, dagangan yang diperjualbelikan banyak yang tidak laku akibat sepi pembeli.

Dengan anjuran pemerintah untuk stay at home dan social distancing membuat aktivitas masyarakat terbatas hanya dirumah saja. Untuk memenuhi kebutuhan hidup juga dilakukan secara Online. Oleh karenanya ini merupakan momentum baik bagi pemilik UMKM untuk meningkatkan pendapatan dengan cara berjualan secara Online. Berjualan secara Online dan rutin melakukan promosi di masa pandemi Covid-19 ini merupakan langkah yang tepat, karena dengan berjualan secara Online produk UMKM masih bisa bersaing di tengah masyarakat dan bisa menghasilkan omzet yang berlipat ganda.

\section{Saran}

Penelitian ini masih terbatas pada sampel penelitian yang digunakan. Penelitian ini hanya terbatas pada dampak pandemi Covid-19 yang dialami oleh pemilik UMKM di desa Suruhan, kabupaten Sukoharjo. Oleh karena itu untuk peneliti selanjutnya disarankan agar memperluas lokasi penelitian dan memperbanyak jumlah responden (narasumber) dengan background kehidupan, pendidikan dan pengalaman yang berbeda untuk mengetahui pengaruhnya terhadap kemampuan dalam menjalankan usaha secara Online. Serta diharapkan mampu memperluas strategi-strategi yang dapat dilakukan oleh pemilik UMKM dalam upaya meningkatkan penjualan di masa pandemi Covid- 19.

\section{UCAPAN TERIMAKASIH}

Atas berkat dan rahmat Allah SWT sehingga penelitian ini dapat berjalan dengan lancar mulai dari proses observasi hingga penyusunan artikel ilmiah. Artikel ini tidak akan sempurna tanpa ada bantuan dan dukungan dari pihak-pihak terkait. Oleh karenanya, penulis mengucapkan rasa terimakasih kepada seluruh narasumber yang sudah berkenan memberikan informasi guna penyusunan artikel ini. Semoga artikel ini dapat memberikan informasi yang bermanfaat bagi para pembaca. 


\section{DAFTAR RUJUKAN}

Aliyani Firdaus, S., Fadilah Ilham, I., Putri Aqidah, L., Aliyani Firdaus, S., Agung Dwi Astuti, S., \& Buchori, I. (2020). Strategi UMKM untuk Meningkatkan Perekonomian selama Pandemi Covid-19 pada saat New Normal. OECONOMICUS Journal of Economics, 5(1), 46-62. https://doi.org/10.15642/oje.2020.5.1.4662

Ayu, S., \& Lahmi, A. (2020). Peran e-commerce terhadap perekonomian Indonesia selama pandemi Covid-19. Jurnal Kajian Manajemen Bisnis, 9(2), 114. https://doi.org/10.24036/jkmb.10994100

Hanoatubun, S. (2020). Dampak Pandemi Covid-19 terhadap Perekonomian Indonesia. Journal of Education, Psychology, and Counseling, 2(1), 147. https://doi.org/10.22216/jbe.v5i2.5313

Hardilawati, W. L., Sandri, S. H., \& Binangkit, I. D. (2019). The Role of Innovation and ECommerce in Small Business. January. https://doi.org/10.2991/iccelst-ss19.2019 .18

Hardilawati, W. laura. (2020). Strategi Bertahan UMKM di Tengah Pandemi Covid-19. Jurnal Akuntansi Dan Ekonomika, 10(1), 89-98.

https://doi.org/10.37859/jae.v10i1.1934

Helmalia, H., \& Afrinawati, A. (2018). Pengaruh E-Commerce Terhadap Peningkatan Pendapatan Usaha Mikro Kecil Dan Menengah Di Kota Padang. JEBI (Jurnal Ekonomi Dan Bisnis Islam), 3(2), 237. https://doi.org/10.15548/jebi.v3i2.182

Juanita, S. (2017). Analisa Strategi Bisnis Penjualan Online. Konferensi Nasional ICT-M Politeknik Telkom, 254-260. http://journals.telkomuniversity.ac.id/knip/ article/view/557

Koperasi, K. (2020). Peraturan Menteri Koperasi Nomor 6 Tahun 2020 Tentang Bantuan Bagi Pelaku Usaha Mikro (BPUM).

Lili Marlinah. (2020). Peluang dan Tantangan UMKM Dalam Upaya Memperkuat Perekonomian Nasional Tahun 2020 Ditengah Pandemi Covid 19. Jurnal Ekonomi, 22(2), 118-124.

Muliati, N. K. (2020). Pengaruh Perekonomian Indonesia di Berbagai Sektor Akibat Corona Virus Disease 2019 (Covid-19). Widya Akuntansi Dan Keuangan, 2(2), 78-86.

https://doi.org/10.32795/widyaakuntansi.v $2 \mathrm{i} 2.874$

Permata Sari, S. (2020). Strategi Meningkatkan Penjualan Di Era Digital. Scientific Journal of Reflection: Economic, Accounting,
Management and Business, 3(3), 291300.

https://doi.org/10.5281/zenodo.3930698

Prabowo, W. A. (2018). Pengaruh Digital Marketingterhadap Organizational Performance Denganintellectual Capital Dan Perceived Qualitysebagai Variabel Intervening Pada Industri Hotel Bintang Tiga Di Jawa Timur. Jurnal Manajemen Pemasaran, 12(2), 101-112. https://doi.org/https://doi.org/10.9744/pe masaran.12.2.101-112

Raco, J. R. (2010). Metode Penelitian Kualitatif Jenis, Karakteristik dan Keunggulannya. PT Gramedia Widiasarana Indonesia.

Reza, F. (2016). Strategi Promosi Penjualan Online Lazada.Co.ld. Jurnal Kajian Komunikasi, 4(1), 64-74. https://doi.org/10.24198/jkk.vol4n1.6

Sugiri, D. (2020). Menyelamatkan Usaha Mikro, Kecil dan Menengah dari Dampak Pandemi Covid-19. Fokus Bisnis: Media Pengkajian Manajemen Dan Akuntansi, 19(1), 76-86. https://doi.org/10.32639/fokusbisnis.v19i1 .575

Sugiyono. (2010). Metode Penelitian Kuantitatif dan Kualitatif dan R\&D. Alfabeta.

Suryani, E. (2021). Analisis Dampak Covid-19 Terhadap UMKM (Studi Kasus: Home Industri Klepon di Kota Baru Driyorejo). Jurnal Inovasi Penelitian, 1(8), 1591-1596.

Yamali, F. R., \& Putri, R. N. (2020). Dampak Covid-19 Terhadap Ekonomi Indonesia. Ekonomis: Journal of Economics and Business, $\quad 4(2), \quad 384$. https://doi.org/10.33087/ekonomis.v4i2.1 79

Yenti Sumarni. (2020). Pandemi Covid-19: Tantangan Ekonomi Dan Bisnis. Al Intaj: Jurnal Ekonomi Dan Perbankan Syariah, 6(2), 46-58.

Yuli Rahmini Suci. (2017). Perkembangan UMKM (Usaha Mikro, Kecil dan Menengah) di Indonesia. Jurnal IImiah Cano Ekonomos, 6(1), 1-31. https://journal.upp.ac.id/index.php/cano/a rticle/view/627

Zubaidah, T., Yenriani, Putri, F. H., \& Pangastuti, N. (2021). Krisis Ekonomi Bangsa Indonesia Dimasa Pandemi Covid-19. Jurnal Nasional Indonesia, 1(2), 103-110.

Zulkipli, \& Muharir. (2021). Dampak Covid-19 Terhadap Perekonomian Indonesia. Jurnal IImiah Mahasiswa Ekonomi Syariah, 1(1), 7-12. 